\section{Trends and predictors of mortality among HIV positive patients in the era of highly active antiretroviral therapy in Uganda}

\author{
John Rubaihayo, ${ }^{1,2}$ \\ Nazarius M. Tumwesigye, ${ }^{1}$ \\ Joseph Konde-Lule, \\ Fredrick Makumbi, ${ }^{1}$ \\ Edith J. Nakku, \\ Henry Wamani, ${ }^{1}$ Michael B. Etukoit ${ }^{3}$ \\ 'Department of Epidemiology and \\ Biostatistics, School of Public Health, \\ College of Health Sciences, Makerere \\ University, Kampala; ' 2 Department of \\ Public Health, School of Health Sciences, \\ Mountains of the Moon University, Fort \\ Portal; ${ }^{3}$ The AIDS Support Organisation, \\ Kampala, Uganda
}

\section{Abstract}

Knowledge of mortality trends and predictors among HIV-positive patients in the era of highly active antiretroviral therapy (HAART) in resource poor settings is still limited. The aim of this study was to describe trends and predictors of mortality among HIV-positive patients in the era of HAART in Uganda. Data from 2004 to 2013 for adult HIV-positive patients ( $\geq 15$ years) obtaining care and treatment from the AIDS Support Organization in Uganda were reviewed for mortality. Descriptive statistics were analyzed by frequencies and cross tabulations. Calendar period was used as a proxy measure for HAART exposure and a time plot of the proportion of HIV-positive patients reporting dead per year was used to describe the trends. Logistic regression was used to determine the predictors of mortality at bivariate and multivariate levels, respectively. We included in the analysis 95,857 HIV positive patients; $64 \%$ were female with median age of 33 years (interquartile range 27-40). Of these 36,133 (38\%) were initiated on ART and a total of 4279 (4.5\%) died; $19.5 \%$ (835/4279) of those who died had an opportunistic infection. Overall, mortality first increased between 2004 and 2006 and thereafter substantially declined $\left(\mathrm{X}_{\text {trend }}^{2}=211.9\right.$, $\mathrm{P}<0.001)$. Mortality was relatively higher in Eastern Uganda compared to other geographical areas. Male gender, older age ( $>45$ years), being from Eastern or Northern Uganda, having none or primary education, being unemployed, advanced immunodeficiency (CD4 count $<100 \mathrm{cell} / \mu \mathrm{L}$ or WHO stage III or IV) and underweight ( $<45 \mathrm{~kg}$ weight) at HAART initia- tion and calendar period 2004-2008 were significant predictors of mortality $(\mathrm{P}<0.001)$. Overall, the expanding coverage of HAART is associated with a declining trend in mortality among HIV positive patients in Uganda. However, mortality trends differed significantly by geographical area and men remain potentially at higher risk of death probably because of delayed initiation on ART. There is urgent need for men targeted interventions for improved ART performance.

\section{Introduction}

In absence of a cure, the human immunodeficiency virus (HIV) still remains one of the greatest public health challenges in the $21^{\text {st }}$ Century with sub-Saharan Africa suffering most of the brunt of the HIV epidemic. However over the past decade, there has been tremendous improvement in the quality of life for persons living with HIV/AIDS (PLHA) in sub-Saharan Africa due to the introduction and expansion of highly active antiretroviral therapy (HAART). ${ }^{1}$ Many studies from sub-Saharan Africa, have highlighted the critical role of antiretroviral therapy in reducing morbidity and mortality associated with HIV/AIDS..$^{2-8}$ However, the greatest challenge for subSaharan Africa has been that most HIV-infected patients present late for ARVS thereby increasing the risk of death in spite of the increasing availability of effective treatment., ${ }^{2,6}$ The recent changes in WHO treatment guidelines, ${ }^{9,10}$ recommending treatment initiation at $350-500 \mathrm{cells} / \mu \mathrm{L}$, were meant to address this challenge in these settings.

Studies that have examined trends in mortality associated with HIV-infection show that mortality while on HAART was substantially higher in sub-Saharan Africa than in developed countries..$^{5}$ A study in England and Wales that examined national trends in death rates and the proportion of deaths attributable to AIDS in the era of effective antiretroviral therapy (ART), and associated risk factors associated with an AIDS-related death found that mortality rate among persons diagnosed with HIV infection aged 15-59 years fell from 217 per 10000 in 1999 to 82 per 10000 in 2008, with significant declines in all age groups and exposure categories. However, late diagnosis (CD4 count $<350$ cells $/ \mu \mathrm{L}$ ) was the most important predictor of death (OR 10.55; 95\%CI: 8.22-13.54)..${ }^{11} \mathrm{~A}$ French cohort study that examined the impact of HAART on mortality in HIVpositive patients found that mortality was significantly associated with older age, ${ }^{12} \mathrm{CD} 4+$ count less than 100 cells $/ \mathrm{mm}^{3}$, anemia, poor nutritional status, hepatitis $\mathrm{C}$ virus (HCV) infection, and low level of formal education. Another study in Peru, a developing country,
Correspondence: John Rubaihayo, Department of Public Health, School of Health Sciences, Mountains of the Moon University, P0 Box 837, Fort Portal, Uganda.

Tel.: + 256.772.490.493

E-mail: rubaihayoj@yahoo.co.uk

Key words: HIV/AIDS; mortality; antiretroviral therapy; Uganda.

Acknowledgements: the authors are grateful to the AIDS Support Organization (TASO) in Uganda for providing the data for the study. We would also like to extend our sincere appreciation to Mountains of the Moon University for the financial support.

Contributions: JR, conceived the study design, wrote the study protocol, collected the data, analyzed and drafted the manuscript; NMT, contributed to the study design, data analysis and review of the manuscript; JKL, contributed to the study design, data analysis and review of the manuscript; HW, contributed to the study design and review of the manuscript; ENJ, contributed to the study design and review of the manuscript; FM, contributed to the study design and review of the manuscript.

Conflict of interest: the authors declare no potential conflict of interest.

Received for publication: 24 April 2015.

Revision received: 29 June 2015.

Accepted for publication: 21 July 2015.

This work is licensed under a Creative Commons Attribution NonCommercial 3.0 License (CC BYNC 3.0).

(c) Copyright J.Rubaihayo et al., 2015

Licensee PAGEPress, Italy

Infectious Disease Reports 2015; 7:5967

doi:10.4081/idr.2015.5967

assessed the effect of HAART on mortality over a 5 year period and recorded a $9 \%$ mortality while on HAART attributed to low CD4 counts (less than 100 cells $/ \mathrm{mm}^{3}$ ) at HAART initiation. $^{13}$

Some authors have attributed the main causes of high mortality in African HIV patients starting HAART were low CD4 cell counts and co-morbidities especially tuberculosis at HAART initiation. ${ }^{2} \mathrm{~A}$ study that investigated the geographical and temporal distribution of TB-HIV deaths in Africa, in the period from 1991 to 2006, ${ }^{6}$ showed that Eastern, Southern, Western, and Middle Africa experienced an upward trend in the number of reported TB-HIV deaths. Eastern Africa was ranked first in absolute upward trend in number of reported TB-HIV deaths, followed by Southern and Western Africa. Uganda and Kenya were categorized as high risk areas for 
TB-HIV related deaths. ${ }^{6}$ In Botswana, the first 633 patients initiated on public HAART were followed for 5 years (2002-2007) and results showed that $86 \%$ of all the deaths occurred in the first 12 months. The majority of deaths were due to advanced HIV disease at HAART initiation, with only a small fraction was attributed to ARV-related toxicities. ${ }^{\text {? }}$

Uganda is ranked among countries with highest HIV burden worldwide, with about 1.5 million people living with HIV/AIDS, about 130,000 new HIV infections each year. ${ }^{14}$ However, in spite of more than 10 years of availability of highly active antiretroviral therapy (HAART), there is paucity of data on trends and predictors of mortality in the different geographical areas. In this study, undertaken in four different geographical areas in Uganda, we sought to describe the mortality patterns and predictors in HIV positive patients in the era of HAART.

\section{Materials and Methods}

\section{Study design}

Observational data of HIV positive patients aged 15 years and above obtaining care and treatment from the AIDS support Organization in Uganda between January 2004 and
December 2013 were retrieved and analyzed. Electronic data was obtained from 4 HIV clinics located in four different geographical areas of Uganda. Annual mortality was assessed and results expressed as a percent of HIV positive patients reported dead out of the total number in care per year. Calendar period was used as a proxy measure of HAART exposure.

\section{Settings}

Data for the study were obtained from TASO, one of the oldest and largest HIV/AIDS care and treatment program in Uganda and sub-saharan Africa. TASO has 11 HIV/AIDS care and treatment centers of excellence (CoE) spread across Uganda. These centers offer comprehensive HIV treatment and care, including pediatric, adolescent and adult HIV care and treatment. TASO HAART program started as part of the National HAART roll-out program in public health facilities in 2004. Being one of the largest HAART providers in the country, TASO attracted a lot of support from different funders supporting HAART programs in sub-Saharan Africa including the President's Emergency Plan for AIDS Relief (PEPFAR) and the Global Fund to Fight AIDS, Tuberculosis and Malaria. Initially, HAART eligibility was based on WHO 2006 guidelines i.e. WHO stage 3 or 4 illness or a CD4 cell count $<200$ cells/ $\mu \mathrm{L}$ for adults and adolescents and WHO stage III, advanced stage
II or stage I with CD4 cell percentage less than $20 \%$ for those more than 18 months of age. ${ }^{15}$ However, in 2010 new HAART guidelines, ${ }^{9}$ that raised the threshold for adults and adolescents to a CD4 cell count $\leq 350$ or WHO clinical stage 3 or 4 irrespective of CD4 cell count, were adopted. ${ }^{16}$ Those who were not eligible for HAART were offered cotrimoxazole prophylaxis. Given the resource constraints and pressing clinical needs, HIV patients could be initiated on HAART basing on clinical presentation without CD4 evaluations. The TASO HAART program has a robust community counseling and social support component including provider initiated and voluntary HIV testing and counseling, distribution of nutritional supplements, monitoring adherence to ART, assessing general clinical conditions of their clients and reporting those severely ill or dead. All services are free of charge including anti-retroviral drugs (ARVs) for those who are eligible. ${ }^{17}$

\section{Sampling and sample size}

Four TASO HIV clinics were purposively selected basing on volume, quality of data and geographical representation. The HIV clinics selected were TASO Mulago HIV clinic in central Uganda, TASO Mbarara HIV clinic in south-western Uganda, TASO Tororo HIV clinic in Eastern Uganda and TASO Gulu HIV clinic in Northern Uganda. All HIV positive adults (15

Table 1. Demographic characteristics of the study participants, total and clinic-specific.

\begin{tabular}{|c|c|c|c|c|c|c|}
\hline Variable & I number, n & HIV clinic, & go HIV clin & arara HIV c & Bulu HIV cli & $(\%) P^{*}$ \\
\hline Gender, $\mathrm{F}(\mathrm{n}=95,857)$ & $61,030(64)$ & $14,435(62)$ & $18,689(66)$ & $15,972(63)$ & $11,934(62)$ & $<0.001$ \\
\hline Age $(n=94,368)$, median $(\mathrm{IQR})$ & $33(27.40)$ & $34(28.42)$ & $33(27.40)$ & $33(27.40)$ & $33(26.40)$ & $<0.001$ \\
\hline$<25 y r s$ & $16,272(17)$ & $3445(15)$ & $5139(18)$ & $4194(17)$ & $3494(19)$ & \\
\hline $25-34 \mathrm{yrs}$ & $35,199(37)$ & $8077(35)$ & $10,589(38)$ & $9853(39)$ & $6680(37)$ & \\
\hline $35-44 y r s$ & $28,293(30)$ & $7306(32)$ & $8251(29)$ & $7635(30)$ & $5101(28)$ & \\
\hline 45yrs and above & $14,613(16)$ & $4215(18)$ & $4093(15)$ & $3544(14)$ & $2761(15)$ & \\
\hline Occupation $(\mathrm{n}=83,084)$ & & & & & & $<0.001$ \\
\hline Paid employee & $14,529(17)$ & $2249(11)$ & $6378(27)$ & $2720(13)$ & $3182(18)$ & \\
\hline Petty trade vendor & $29,890(36)$ & $6589(32)$ & $10,437(46)$ & $5187(24)$ & $7677(43)$ & \\
\hline Peasant & $33,506(40)$ & $10,953(52)$ & 4257 (18) & $12,007(56)$ & $6289(35)$ & \\
\hline Others & $5159(6)$ & $1048(5)$ & $2016(9)$ & $1322(7$ & $773(4)$ & \\
\hline Education $(\mathrm{n}=85,957)$ & & & & & & $<0.001$ \\
\hline None & $18,250(21)$ & $5761(28)$ & $2585(11)$ & $5131(21)$ & $4773(27)$ & \\
\hline Primary & $48,063(56)$ & $11,397(54)$ & $12,620(55)$ & $14,228(58)$ & $9818(55)$ & \\
\hline Secondary & $16,347(19)$ & $3095(15)$ & $6541(28)$ & $3972(17)$ & $2739(15)$ & \\
\hline Tertiary or above & $3297(4)$ & $616(3)$ & $1309(6)$ & $791(3)$ & $581(3)$ & \\
\hline Marital status $(86,137)$ & & & & & & $<0.001$ \\
\hline Single/never married & $5338(6)$ & $1474(7)$ & $1609(7)$ & $1563(6)$ & $692(4)$ & \\
\hline Married/cohabiting & $40,689(47)$ & $11,271(54)$ & $9832(43)$ & $11,097(46)$ & 8489 (47) & \\
\hline Divorced & $16,058(19)$ & $2679(13)$ & $6182(27)$ & $4053(17)$ & $3144(17)$ & \\
\hline Widowed & $19,797(23)$ & $4729(23)$ & $4459(19)$ & $6108(25)$ & $4501(25)$ & \\
\hline Others & $4255(5)$ & $686(3)$ & $968(4)$ & $1473(6)$ & $1128(6)$ & \\
\hline Religion/faith $(\mathrm{n}=85,256)$ & & & & & & $<0.001$ \\
\hline Catholic & $39,508(46)$ & $8816(42)$ & $8690(38)$ & $9025(38)$ & $12,977(73)$ & \\
\hline Protestant & $29,807(34)$ & $6898(33)$ & $8690(34)$ & $11,923(51)$ & $3073(17)$ & \\
\hline Muslim & $6621(8)$ & $1692(8)$ & $3160(14)$ & $1310(6)$ & $459(3)$ & \\
\hline Pentecostal & $6635(8)$ & 2358 (11) & $2454(11)$ & $838(3)$ & $985(5)$ & \\
\hline Others & $2685(3)$ & $1064(5)$ & $795(3)$ & $508(2)$ & $318(2)$ & \\
\hline
\end{tabular}

*Chi-squared or Mann Whitney test. 
years and above) who attended at least once at the selected HIV clinics in the period from $1^{\text {st }}$ January 2004 to $31^{\text {st }}$ December 2013 were included in the study.

\section{Data collection}

Data collection procedure was according to an established protocol across all TASO HIV clinics. In brief, each client is expected to attend the clinic at least once a month. At each clinic visit, data per client is collected on a standardized case report form (CRF) detailing the client's demographic characteristics, clinical condition, medical history, prophylaxis use, OI diagnosis and treatment given. Mortality data was collected using standardized death notification forms. The information was then compiled and entered into the TASO electronic data base using EPIINF0 vs3 in Access format. Data for the study were extracted by Data mangers at the study clinics, delinked from overt identifiers and then handed over for analysis.

\section{Statistical analysis}

Statistical analysis was undertaken using Stata 13 (Stata Corp, Collage station, TX, USA). Descriptive statistics were presented as frequencies for categorical data and median with interquartile range (IQR) for numeric data. Differences in variables were tested using chi-squared test or Wilcoxon rank-sum test as appropriate. A time plot of the proportion of HIV positive patients reported dead each year was used to describe the trends. The significance of the trends were tested using $\mathrm{X}^{2}$ trend. Logistic regression was used to determine predictors of mortality at univariate and multivariate level respectively. Variables showing significant association in univariate analysis were included in multivariate logistic regression to calculate adjusted odds ratios with $95 \%$ confidence intervals. All significance tests were two sided and a P-value $<0.05$ was considered significant.

\section{Ethical clearance}

The study obtained ethical clearance from Makerere University School of Public Health Higher Degrees Research and Ethics committee and the Uganda National Council for Science and Technology. Informed consent from study participants was not required as this was routinely collected operational data and the above ethical committees waived the need for consent. However, written consent was obtained from TASO for conducting study and publication of findings with any accompanying images.

\section{Results}

A total of 95,857 HIV-positive patients were included in the analysis; $64 \%$ were female with median age of 33 years (IQR, 27-40). Most of them had primary or no formal education (77\%), and without formal employment (living as subsistence farmers or self employed petty trade vendors, $76 \%$ ) (Table 1).

Overall HAART coverage increased from $3 \%$ $(709 / 23,577)$ in 2004 to $74 \%(22,964 / 31,173)$ in 2013 (Table 2). The proportion of men accessing HAART was relatively lower compared to women though out the study period i.e. only $30 \%$ in 2004 and $37 \%$ in 2013 (Table 3).

At the commencement of HAART, significant differences were observed between male and female ART clients with men being older (median age 35 yrs, IQR 29-42 vs 32 yrs IQR $26-39, \mathrm{P}<0.0001)$ and likely to be more severely ill (WHO clinical stage III and IV $36 \%$ vs $33 \%$, $\mathrm{P}<0.0001$ ) (Table 3). The most prescribed HAART regimen was a combination of zidovudine, lamivudine with nevirapine or efavirenz (ZDV+3TC+NVP/EFV) (54\%). The median age at the start of HAART was 33 years (IQR 2740). The median CD4 cell count at the start of HAART in the period 2004-2008 was 195 (IQR 87-328) and 263 (IQR, 146-370) in the period 2009-2013 (Table 3).
From 2004 to 2013 , a total of 4279 (4.5\%) died, among them $2477(58 \%)$ were female and 1789 (42\%) were male; 19.5\% (835/4279) of those who died had an OI. Mortality first increased in early stages of HAART (calendar period 2004-2008) and thereafter substantially declined $\left(\mathrm{X}_{\text {trend }}^{2}=211.9, \mathrm{P}<0.001\right)$. Overall the proportion of HIV positive patients who died slightly increased from around 5\% in 2004 to $6 \%$ in 2006-7, then consistently declined up to around $2 \%$ in $2013\left(\mathrm{X}^{2}\right.$ trend $\left.=211.9, \mathrm{P}<0.001\right)$. Mortality was highest at Tororo HIV clinic (Eastern Uganda) in which the proportion of HIV positive patients who died first increased from around $7 \%$ in 2004 to $9.6 \%$ in 2007 and thereafter reduced to around $4 \%$ in 2013 but the trend was marginally significant $\left(\mathrm{X}_{\text {trend }}=0.52, \mathrm{P}=0.47\right.$ ) (Figure 1). Gulu HIV clinic (Northern Uganda) recorded the highest mortality in 2004 at about $8 \%$ which thereafter reduced consistently to around $2 \%$ in 2013 $\left(\mathrm{X}_{\text {trend }}^{2}=210.2, \mathrm{P}<0.001\right)$. At Mbarara HIV clinic (South-western Uganda), the proportion of HIV positive patients who died slightly increased from around $4 \%$ in 2004 to $5 \%$ in 2006 , but thereafter consistently declined up to around $2 \%$ in $2013\left(\mathrm{X}_{\text {trend }}^{2}=15.0, \mathrm{P}=0.0001\right)$. Mortality was relatively lower at Mulago HIV clinic (Central Uganda) with the proportion reported dead slightly increased from $3 \%$ in 2004 to $4.3 \%$ in 2006 and thereafter consistently declined to $0.7 \%$ in $2013\left(\mathrm{X}_{\text {trend }}^{2}=100.2\right.$, $\mathrm{P}<0.001$ ) (Figure 1).

In multivariate analysis, the odds of death were significantly higher in male gender with men being $37 \%$ more at risk compared to women (OR 1.37, 95\%CI 1.26-1.49, $\mathrm{P}<0.001$ ). The odds of death were $15 \%$ higher in age $>45$ years compared to those $<25$ year (OR 1.15, 95\%CI 1.01-1.33). Patients who were unemployed/subsistence farmers were $28 \%$ more likely to die compared to these who are formally employed (OR 1.28, 95\%CI 1.15-1.43, $\mathrm{P}<0.001)$. Patients from eastern Uganda were 3 times more likely to die compared to patients from central Uganda (OR 3.18, 95\% CI 2.80-3.61

Table 2. Number of study participants accessing highly active antiretroviral therapy (ART) in the period 2004 to 2013 , total and clinic-specific.

\begin{tabular}{lcccccccccc} 
Year & \multicolumn{2}{c}{ Gulu HIV clinic } & \multicolumn{2}{c}{ Mulago HIV clinic } & \multicolumn{2}{c}{ Mbarara HIV clinic } & \multicolumn{2}{c}{ Tororo HIV clinic } & \multicolumn{2}{c}{ All sites } \\
& In care & On ART (\%) & In care & On ART (\%) & In care & On ART (\%) & In care & On ART (\%) & In care & On ART ( \%) \\
2004 & 2895 & $13(0.4)$ & 6292 & $363(5.8)$ & 8121 & $125(1.5)$ & 6269 & $208(3.3)$ & 23,577 & $709(3.0)$ \\
2005 & 4625 & $349(7.5)$ & 596 & $936(15.7)$ & 5837 & $978(16.8)$ & 6491 & $463(7.1)$ & 22,913 & $2726(11.9)$ \\
\hline 2006 & 4938 & $569(11.5)$ & 5174 & $1066(20.6)$ & 5984 & $1030(17.2)$ & 54 & $491(9.1)$ & 21,496 & $3156(14.7)$ \\
2007 & 5260 & $1338(25.4)$ & 5332 & $1700(31.9)$ & 6632 & $2182(32.9)$ & 6723 & $1015(15.1)$ & 23,947 & $6235(26.0)$ \\
\hline 2008 & 5739 & $1836(32.0)$ & 5802 & $2111(36.4)$ & 682 & $2124(31.1)$ & 8221 & $1972(24.0)$ & 26,582 & $8043(30.2)$ \\
2009 & 7291 & $2695(37.0)$ & 6466 & $2571(33.6)$ & 7382 & $2756(37.3)$ & 9893 & $2813(28.4)$ & 31,032 & $10,835(34.9)$ \\
\hline 2010 & 7266 & $2927(40.3)$ & 8012 & $3155(39.4)$ & 756 & $2982(39.4)$ & 10613 & $4304(40.5)$ & 33,451 & $13,368(40.0)$ \\
2011 & 7967 & $4256(53.4)$ & 9297 & $4247(45.7)$ & 9262 & $3891(42.0)$ & 9733 & $5277(54.2)$ & 36,259 & $17,671(48.7)$ \\
\hline 2012 & 8389 & $5051(60.2)$ & 9728 & $4669(48.0)$ & 9789 & $4558(46.6)$ & 8333 & $6452(77.4)$ & 36,236 & $20,730(57.2)$ \\
2013 & 8361 & $5789(69.2)$ & 7493 & $5787(77.2)$ & 7199 & $4707(65.4)$ & 8122 & $6681(82.3)$ & 31,175 & $22,964(73.7)$ \\
\hline
\end{tabular}


$\mathrm{P}<0.001)$. WHO stage III and IV at HAART initiation increased the odds of death by $77 \%$ compared to those in WHO stages I and II (OR 1.77, 95\%CI 1.62-1.93, P<0.001). CD4 count $<100$ cells $/ \mu \mathrm{L}$ of blood increased the odds of death 3 times compare to patients whose CD4 count was $>350$ cells/ $\mu \mathrm{L}$ of blood (OR 3.37, 95\%CI 2.78-4.09, $\mathrm{P}<0.001)$. Patients with a baseline weight $<45 \mathrm{~kg}$ were twice more likely to die compared to patients whose baseline weight was $>60 \mathrm{~kg}$ (OR 1.95, 95\% CI 1.65-2.31, $\mathrm{P}<0.001$ ) and patients who were in care in calendar period 2004-2008 were more likely to die compare to patients who were in care in calendar period 2009-2013 (OR 2.21, 95\%CI 2.01$2.41, \mathrm{P}<0.001$ ) (Table 4).

\section{Discussion}

This study gives an insight on trends and predictors of mortality in the HAART era in Uganda. The nature of patients included in the study is almost similar to other HIV positive patients on HAART in resource poor settings. Our results were consistent with those obtained from other previous studies in resource-constrained settings. ${ }^{2,5,18-20}$ Mortality first increased in early stages of HAART (calendar period 2004-2008) but later declined consistently attributed to the expanded coverage of HAART. ${ }^{21,22}$ However increasing use of cotrimoxazole prophylaxis and introduction of improved therapeutic drugs (fluconazole, acyclovir, etc) could also account for some of the observed decline in mortality over time..$^{23-28}$

In our study, we observed high mortality among those initiated on HAART in WHO clinical stage III and IV or CD4 cell count $<100$ cells/ $\mu \mathrm{L}$ especially in the period between 2004 and 2008. These results are comparable to other reports from other studies. ${ }^{20,22,29-34}$ In our study, mortality was 3 times higher in patients who initiated HAART with CD4 count less or equal to 100 cells/ $\mu \mathrm{L}$ compared to those who were initiated on HAART with CD4 above 350 cell $/ \mu \mathrm{L}$. These results are almost similar to those described elsewhere. ${ }^{2,20,35,36}$ However, it should also be noted that in Uganda, in spite of availability of free HAART and cotrimoxazole prophylaxis, only $13 \%$ of adult women and $11 \%$

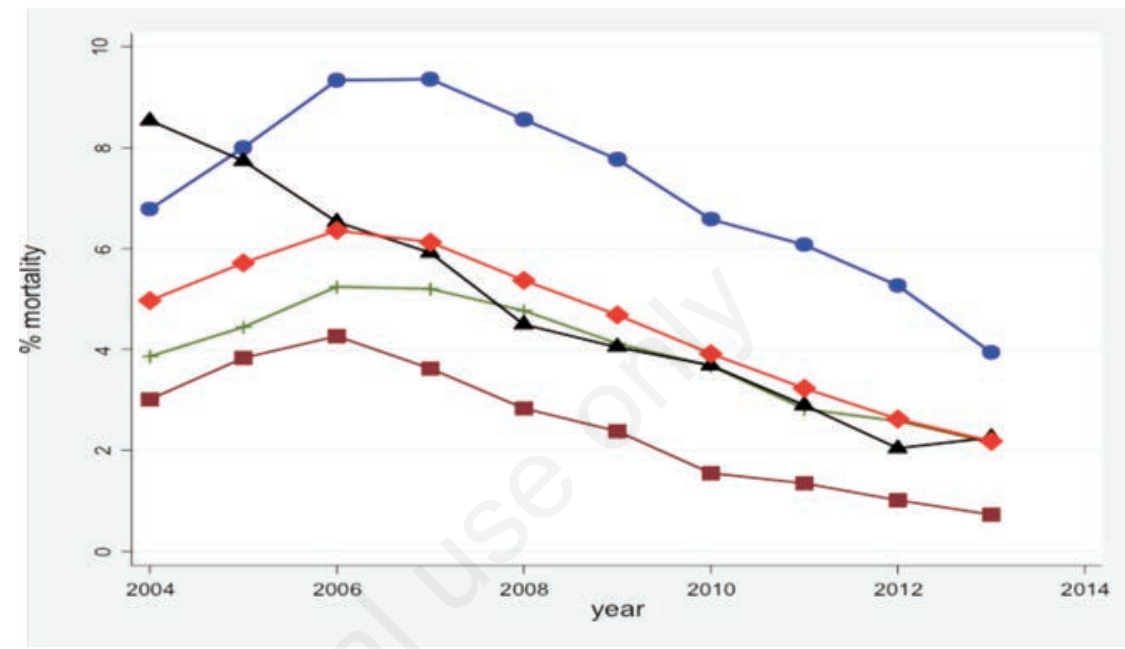

Figure 1. Mean annual mortality expressed as a percent of HIV positive patients reported dead out of the total number in care per month at each of the four clinics: Tororo HIV clinic (blue line), Mulago HIV clinic (brown line), Mbarara HIV clinic (green line), Gulu HIV clinic (black line) and all sites (redline).

Table 3. Baseline characteristics of the study participants at commencement of highly active antiretroviral therapy (ART), total and gender specific $(\mathrm{N}=36,372)$.

\begin{tabular}{|c|c|c|c|c|}
\hline Characteristic & Total & Female & Male & P* \\
\hline Age, median (interquartile range) & $33(27.40)$ & $32(26.39)$ & $35(29.42)$ & $<0.001$ \\
\hline WHO stage, III \& IV, n (\%) & $30,185(34)$ & $18,793(33)$ & $11,392(36)$ & $<0.001$ \\
\hline 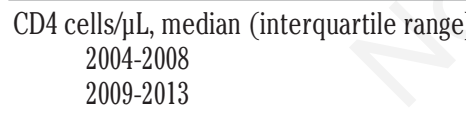 & $\begin{array}{c}195(87,328) \\
263(146,370)\end{array}$ & $\begin{array}{c}195(87,334) \\
273(159,377)\end{array}$ & $\begin{array}{c}194(87,318) \\
244(123,354)\end{array}$ & $\begin{array}{l}<0.001 \\
<0.001\end{array}$ \\
\hline $\begin{array}{l}\text { ART regimen }(2005-2013), \mathrm{n}(\%) \\
\mathrm{d} 4 \mathrm{~T}+3 \mathrm{TC}+\mathrm{NVP} / \mathrm{EFV} \\
\mathrm{ZDV}+3 \mathrm{TC}+\mathrm{NVP} / \mathrm{EFV} \\
\mathrm{TDF}+\mathrm{FTC}+\mathrm{LPV} / \mathrm{r} \\
\text { TDF+3TC+NVP/EFV } \\
\text { Others } \\
\end{array}$ & $\begin{array}{c}6728(9) \\
40,784(54) \\
16,218(21) \\
5350(7) \\
7120(9) \\
\end{array}$ & $\begin{array}{c}4874(9) \\
27,408(54) \\
10495(21) \\
3472(7) \\
4789(9) \\
\end{array}$ & $\begin{array}{c}1854(7) \\
13,376(53) \\
5723(23) \\
1878(7) \\
2331(9) \\
\end{array}$ & $<0.001$ \\
\hline Median weight, kg (interquartile range) & $54(47.61)$ & $54(47.61)$ & $55(49.62)$ & $<0.001$ \\
\hline $\begin{array}{l}\text { Calendar year of ART initiation } \\
2004 \\
2005 \\
2006 \\
2007 \\
2008 \\
2009 \\
2010 \\
2011 \\
2012 \\
2013\end{array}$ & $\begin{array}{c}592(2) \\
2870(8) \\
1965(5) \\
3789(10) \\
2560(7) \\
4549(12) \\
5341(15) \\
4116(11) \\
6449(18) \\
4145(11)\end{array}$ & $\begin{array}{c}415(70) \\
2035(71) \\
1315(67) \\
2483(66) \\
1675(65) \\
2972(65) \\
3484(65) \\
2631(64) \\
4157(64) \\
2600(63)\end{array}$ & $\begin{array}{c}177(30) \\
835(29) \\
650(33) \\
1306(34) \\
885(35) \\
1573(35) \\
1857(35) \\
1485(36) \\
2292(36) \\
1545(37)\end{array}$ & $<0.001$ \\
\hline
\end{tabular}


Table 4. Factors associated with mortality among HIV+ individuals from 4 different geographical areas in Uganda, Odds Ratio (OR, 95\% CI).

\begin{tabular}{|c|c|c|c|c|c|c|}
\hline Patient factor & Not at risk & Died, n (\%) & Crude OR ratio & $\mathbf{P}$ & Adjusted OR* & $\mathbf{P}$ \\
\hline $\begin{array}{l}\text { Sex } \\
\quad \text { Female } \\
\quad \text { Male } \\
\quad \text { Not recorded }\end{array}$ & $\begin{array}{c}61,031 \\
32,583 \\
2244\end{array}$ & $\begin{array}{l}2477(4.1) \\
1789(5.5) \\
13(0.58)\end{array}$ & $\begin{array}{c}1 \\
1.37(1.29-1.46) \\
0.14(0.08-0.24)\end{array}$ & $\begin{array}{l}<0.001 \\
<0.001\end{array}$ & $\begin{array}{c}1 \\
1.37(1.26-1.49) \\
0.19(0.17-0.71)\end{array}$ & $\begin{array}{c}<0.001 \\
0.053\end{array}$ \\
\hline $\begin{array}{l}\text { Age } \\
\quad<25 y r s \\
25-34 \\
35-44 \\
\quad \geq 45 \\
\quad \text { Not recorded }\end{array}$ & $\begin{array}{c}16,235 \\
35,193 \\
28,272 \\
14,592 \\
1566\end{array}$ & $\begin{array}{l}684(4.2) \\
1474(4.2) \\
1318(4.7) \\
790(5.4) \\
13(0.8)\end{array}$ & $\begin{array}{l}1 \\
0.99(0.90-1.09) \\
1.11(1.01-1.22) \\
1.30(1.17-1.44) \\
0.19(0.11-0.33)\end{array}$ & $\begin{array}{l}0.896 \\
0.028 \\
<0.001 \\
<0.001\end{array}$ & $\begin{array}{c}1 \\
1.03(0.91-1.16) \\
1.04(0.92-1.18) \\
1.15(1.01-1.33) \\
2.82(0.65-12.33)\end{array}$ & $\begin{array}{l}0.666 \\
0.491 \\
0.038 \\
0.167\end{array}$ \\
\hline $\begin{array}{l}\text { Geographical location } \\
\text { Central } \\
\text { Eastern } \\
\text { Western } \\
\text { Northern }\end{array}$ & $\begin{array}{l}28,353 \\
23,126 \\
25,268 \\
19,111\end{array}$ & $\begin{array}{l}638(2.2) \\
1779(7.7) \\
990(3.9) \\
872(4.6)\end{array}$ & $\begin{array}{c}1 \\
3.62(3.30-3.97) \\
1.77(1.60-1.96) \\
2.08(1.87-2.30)\end{array}$ & $\begin{array}{l}<0.001 \\
<0.001 \\
<0.001\end{array}$ & $\begin{array}{c}1 \\
3.18(2.80-3.61) \\
1.81(1.58-2.07) \\
1.46(1.26-1.68)\end{array}$ & $\begin{array}{l}<0.001 \\
<0.001 \\
<0.001\end{array}$ \\
\hline $\begin{array}{l}\text { Education } \\
\text { None } \\
\text { Primary } \\
\text { Secondary } \\
\text { Tertiary } \\
\text { Not recorded } \\
\end{array}$ & $\begin{array}{c}18,250 \\
48,064 \\
16,347 \\
3297 \\
9900\end{array}$ & $\begin{array}{l}952(5.2) \\
2357(4.9) \\
654(4.0) \\
119(3.6) \\
197(2.0)\end{array}$ & $\begin{array}{c}1.47(1.21-1.78) \\
1.38(1.14-1.66) \\
1.11(0.91-1.36) \\
1 \\
0.54(0.43-0.68)\end{array}$ & $\begin{array}{c}<0.001 \\
<0.001 \\
0.292 \\
<0.001\end{array}$ & $\begin{array}{c}0.94(0.73-1.21) \\
0.96(0.78-1.26) \\
0.89(0.69-1.14) \\
1 \\
0.59(0.41-0.85)\end{array}$ & $\begin{array}{l}0.629 \\
0.975 \\
0.359 \\
0.004\end{array}$ \\
\hline $\begin{array}{l}\text { Religion/Faith } \\
\text { Pentecostal } \\
\text { Protestant } \\
\text { Muslim } \\
\text { Catholic } \\
\text { Others } \\
\text { Not recorded }\end{array}$ & $\begin{array}{c}6635 \\
29,807 \\
6621 \\
39,508 \\
2686 \\
10,601\end{array}$ & $\begin{array}{l}261(3.9) \\
1390(4.7) \\
288(4.3) \\
1984(5.0) \\
130(4.8) \\
226(2.1)\end{array}$ & $\begin{array}{c}1 \\
1.20(1.04-1.37) \\
1.11(0.93-1.32) \\
1.30(1.13-1.47) \\
1.24(1.00-1.54) \\
0.53(0.44-0.64)\end{array}$ & $\begin{array}{l} \\
\\
0.0098 \\
0.229 \\
0.0001 \\
0.048 \\
<0.001\end{array}$ & & \\
\hline $\begin{array}{l}\text { Occupation } \\
\text { Formally employed } \\
\text { Unemployed/self employed/ } \\
\text { subsistence farmer } \\
\text { Not recorded } \\
\end{array}$ & $\begin{array}{l}14,529 \\
68556 \\
12,773\end{array}$ & $\begin{array}{l}528(3.6) \\
3428(5.0) \\
323(2.1)\end{array}$ & $\begin{array}{c}1 \\
1.39(1.27-1.53) \\
0.69(0.60-0.79)\end{array}$ & $\begin{array}{l}<0.001 \\
<0.001\end{array}$ & $\begin{array}{c}1 \\
1.28(1.15-1.43) \\
0.87(0.75-1.01)\end{array}$ & $\begin{array}{l}<0.001 \\
0.072\end{array}$ \\
\hline $\begin{array}{l}\text { Marital status } \\
\text { Single/never married } \\
\text { Married/cohabiting } \\
\text { Divorced } \\
\text { Widowed } \\
\text { Others } \\
\text { Not recorded }\end{array}$ & $\begin{array}{c}5338 \\
40,689 \\
16,058 \\
19,798 \\
4255 \\
9720\end{array}$ & $\begin{array}{l}272(5.1) \\
2036(5.0) \\
707(4.4) \\
835(4.2) \\
234(5.5) \\
195(2.0)\end{array}$ & $\begin{array}{c}1 \\
0.98(0.86-1.12) \\
0.86(0.74-0.99) \\
0.82(0.71-0.94) \\
1.08(0.91-1.30) \\
0.38(0.32-0.46)\end{array}$ & $\begin{array}{l}0.773 \\
0.036 \\
0.005 \\
0.379 \\
<0.001\end{array}$ & & \\
\hline $\begin{array}{l}\text { WHO stage at start of ART } \\
\text { I\&II } \\
\text { III\&IV } \\
\text { Not recorded }\end{array}$ & $\begin{array}{c}24,337 \\
10,716 \\
1319 \\
\end{array}$ & $\begin{array}{l}1516(6.2) \\
1068(10) \\
210(15.9)\end{array}$ & $\begin{array}{c}1 \\
1.67(1.53-1.81) \\
2.85(2.44-3.33) \\
\end{array}$ & $\begin{array}{l}<0.001 \\
<0.001\end{array}$ & $\begin{array}{l}1.77(1.62-1.93) \\
1.82(1.54-2.15)\end{array}$ & $\begin{array}{l}<0.001 \\
<0.001\end{array}$ \\
\hline $\begin{array}{l}\text { CD4 cell count at start of ART } \\
0-100 \\
101-350 \\
>350\end{array}$ & $\begin{array}{l}3824 \\
9372 \\
3158\end{array}$ & $\begin{array}{l}524(13.7) \\
601(6.4) \\
153(4.8)\end{array}$ & $\begin{array}{c}3.12(2.58-3.77) \\
1.35(1.12-1.61) \\
1\end{array}$ & $\begin{array}{l}<0.001 \\
<0.001\end{array}$ & $\begin{array}{c}3.37(2.78-4.09) \\
1.47(1.22-1.76) \\
1\end{array}$ & $\begin{array}{l}<0.001 \\
<0.001\end{array}$ \\
\hline Not recorded & 20,018 & $1516(7.6)$ & $1.61(1.36-1.91)$ & $<0.001$ & $1.94(1.62-2.32)$ & $<0.001$ \\
\hline $\begin{array}{l}\text { Weight at start of ART } \\
\quad<45 \mathrm{~kg} \\
45-60 \mathrm{~kg} \\
>60 \mathrm{~kg} \\
\text { Not recorded }\end{array}$ & $\begin{array}{c}4010 \\
13,876 \\
5745 \\
12,741\end{array}$ & $\begin{array}{l}420(10.5) \\
925(6.7) \\
263(4.6) \\
1186(9.3)\end{array}$ & $\begin{array}{c}2.44(2.08-2.86) \\
1.49(1.29-1.71) \\
1 \\
2.14(1.86-2.46)\end{array}$ & $\begin{array}{l}<0.001 \\
<0.001 \\
<0.001\end{array}$ & $\begin{array}{c}1.95(1.65-2.31) \\
1.26(1.09-1.45) \\
1 \\
1.51(1.31-1.74)\end{array}$ & $\begin{array}{l}<0.001 \\
<0.001 \\
<0.001\end{array}$ \\
\hline $\begin{array}{c}\text { Calendar period } \\
2004-2008 \\
2009-2013 \\
\end{array}$ & $\begin{array}{l}58,832 \\
37,026 \\
\end{array}$ & $\begin{array}{l}3081(5.2) \\
1198(3.2)\end{array}$ & $\begin{array}{c}1.65 \text { (1.54-1.77) } \\
1 \\
\end{array}$ & $<0.001$ & $\begin{array}{c}2.21(2.01-2.41) \\
1 \\
\end{array}$ & $<0.001$ \\
\hline
\end{tabular}

OR, odds ratio; Cl, confidence interval. *Adjusted ORs for calendar period after controlling for sex, geographical location, occupation, baseline CD4 count and baseline weight of individual HIV positive patients. 
of adult men ever tested and known their HIV status implying that majority were more likely to present for treatment with advanced HIV disease. ${ }^{37}$ In fact, previous studies in Uganda have shown $40 \%$ of those eligible for HAART present with late disease stage for treatment resulting into poor prognostic outcomes. ${ }^{34,38,39}$ In the current study, 19.5\% (835/4279) of those who died had an opportunistic infection. Patients with CD4-cell counts $<100$ cells/ $\mu \mathrm{L}$ were more likely to experience an $0 \mathrm{I}$, with men being at higher risk for life threatening OIs such as mycobacterium tuberculosis and cryptococcal meningitis compared to women.

A study in Ivory coast involving a cohort of 792 HIV infected adults found the incidence of mortality and severe morbidity was high among patients whose pre-HAART CD4 count was $<350$. These patients reported with severe infections including invasive bacterial diseases (49\%) and TB (38\%) that increased the risk of death. ${ }^{33}$

In our study, male gender was a strong predictor of mortality (OR $1.4 ; 1.3-1.5)$. This is consistent with several other previous studies which show gender differences in ART outcomes. $^{20,31,40,41}$ However, our findings differ from other studies which found no significant difference in the risk of death between gender. ${ }^{2,5,19}$ Potential confounders such as gender differences in treatment access and adherence, socio-cultural differences, HIV-related stigma and health seeking behavioral differences could probably explain this gender difference. However some studies have attributed this problem to men's reluctance to go for early HIV testing hence late HAART initiation associated with poor prognostic outcomes. ${ }^{8}$ Old age and low weight (proxy indicator for malnutrition) at start of HAART were significant predictors of mortality in our study. Patients with a weight $<45 \mathrm{~kg}$ were more than twice at higher risk of death (OR 2.4, 95\% CI 2.1-2.8) compared to those above $60 \mathrm{~kg}$ at HAART initiation. This is consistent with findings from other studies in resource poor settings. , $^{219,31,42}$ Zachariah and colleagues demonstrated that mortality increased with severity of malnutrition in HIV-infected patients starting HAART in Tanzania. In their study they found 1-year mortality at $46.8 \%$ for those with severe malnutrition (BMI $<16 \mathrm{~kg} / \mathrm{m}^{2}$ ) compared to only $13.7 \%$ mortality in patients with normal nutritional status (BMI $\left.\geq 18.5 \mathrm{~kg} / \mathrm{m}^{2}\right){ }^{42}$ This is probably because malnutrition (under nutrition) is associated with poverty increases the risk of anemia, compromises immunity and therefore undermines the effectiveness of HAART resulting in increased the risk of OIs and death. ${ }^{43}$ Older age ( $>45$ yrs) was strongly associated with mortality OR 1.30 (1.17-1.44) compared to younger age $(<25 \mathrm{yrs})$ which is also consistent with previous studies. ${ }^{31}$ A study in Uganda found that a large percentage of elderly per- sons (33.3\%) were malnourished. ${ }^{44}$ The risk of death was also strongly associated with calendar period consistent with a previous study which assessed ART outcomes in African and Asian HIV programs. ${ }^{31}$ In the early year of HAART, the focus were the severely ill HIV positive patients (CD4 cell count $<200$ cells/ $\mu \mathrm{L}$ ) while in later years of HAART the threshold for HAART eligibility changed to include even those with CD4 cell count of up to $350 \mathrm{cell} / \mu \mathrm{L} .{ }^{9}$ However increase in mortality observed between 2004 and 2006 could be due to poor mortality data collection in the early years HAART and which may have improved in the later years.

Having no education or only primary education was a strong predictor of mortality among HIV patients in Uganda. The odds of death were 1.47 (95\%CI 1.21-1.78) higher in patients with no formal education and 1.38 (95\%CI 1.14-1.60) higher in patients with only primary education compared to those with tertiary education. Our findings are consistent with those got from other previous studies. ${ }^{45,46}$ However differed from another study that found no association of education with mortality in Tanzania. ${ }^{35}$

In our study, the odds of death were worse if a patient was from eastern Uganda (OR 3.6, 95\%CI 3.3-4.0, $\mathrm{P}<0.001)$ or northern Uganda (OR 2.1, 95\%CI 1.9-2.3, $\mathrm{P}<0.001$ ) which is consistent with other studies that also found geographical variation in HAART effect on mortality. ${ }^{5}$ Geographical location may be related to timely access to quality health care as most rural centers have clients who have to travel long distances to access services involving high transport costs. Very little is known about the role of religion in mortality among HIV patients. In our study we found the odds of death were higher among Catholics (OR 1.3, 95\%CI 1.1-1.5) and Protestants (OR 1.2, 95\%CI 1.0-1.4) compared to Born-again/Pentecostal Christians. This difference could probably be explained by behavioral lifestyles. ${ }^{35}$ Patients who were unemployed/subsistence farmers had a higher risk of death (OR 1.4, 95\%CI 1.31.5) compared to the employed. This finding is consistent with studies elsewhere in which it was shown that lack of education or unemployment were strongly associated with poverty and hence poor prognostic outcomes on HAART. ${ }^{13,35,46}$

\section{Limitations}

This study had a number of limitations. First we were not able to determine the exact cause of deaths, and to attribute all of them to HIV could over estimate HIV-related mortality. Secondly, the data were collected for operational purposes and so to a certain degree may have underreported some of the events. For example our analysis was limited to the mortality data captured in the TASO data base which probably under-estimates the true mortality risk, given the fact that many deaths may have never been reported especially among those who transferred out of program care. Another limitation was that the role of adherence to HAART was not assessed especially among the unemployed/peasant farmers who had a relatively higher risk of death compared to those who were employed aware that poor adherence to HAART may result into poor prognostic outcomes. ${ }^{47,48}$ However this may not necessarily be the reason given that previous studies in the same settings reported $78-86 \%$ had good adherence to HAART (>95\%). ${ }^{34,49}$ Nevertheless, the study provides additional evidence of a significant impact of HAART on mortality despite the above limitations.

\section{Conclusions}

This was rather a long observational study (10 years) that reflects the operational realities in most resource poor settings. HAART coverage in these settings has substantially increased by over 70\% since HAART roll out in 2004. Increased HAART coverage has significantly altered mortality trends from increasing to declining trends in all the regions of Uganda studied. Fewer men than women were on HAART (34\%) and the hazards of death were greater in men compared to women (OR 1.4; 95\% CI 1.3-1.5) providing additional evidence of an going challenge of men performance while on HAART. Mortality trends differed significantly by geographical area and male gender, older age ( $>45$ years), being from Eastern or Northern Uganda, low levels of education, being unemployed, advanced immunodeficiency (CD4 count $<100$ cell $/ \mu \mathrm{L}$ ) or WHO stage III or IV) and malnutrition ( $<45 \mathrm{~kg}$ weight) at HAART initiation were significant predictors of mortality in these settings. This therefore calls for targeted interventions for those highly at risk of death. There is urgent need for men targeted interventions for improved ART performed.

\section{References}

1. UNAIDS. Access to antiretroviral therapy in Africa: satus report on progress towards 2015 targets. Geneva: UNAIDS; 2014. Contract No.: 10-07-2014.

2. Etard JF, Ndiaye I, Thierry-Mieg M, et al. Mortality and causes of death in adults receiving highly active antiretroviral therapy in Senegal: a 7-year cohort study. AIDS 2006;20:1181-9.

3. Miiro G, Todd J, Mpendo J, et al. Reduced morbidity and mortality in the first year 
after initiating highly active anti-retroviral therapy (HAART) among Ugandan adults. Trop Med Int Health 2009;14:556-63.

4. Munderi P, Watera C, Nakitingi J, et al. Survival and causes of death, 2 years after the introduction of antiretroviral therapy in Africa: a historical cohort comparison in Entebbe, Uganda. Sixteenth International AIDS Conference; Toronto2006.

5. Braitstein P, Brinkhof MW, Dabis F, et al. Mortality of HIV-1-infected patients in the first year of antiretroviral therapy: comparison between low-income and highincome countries. Lancet 2006;367:817-24.

6. Uthman OA, Yahaya V, Ashfaq I, et al. A trend analysis and sub-regional distribution in number of people living with HIV and dying with TB in Africa, 1991 to 2006. Int J Health Geograph 2009;8:65.

7. Bussmann H, Wester CW, Ndwapi N, et al. Five year outcomes of initial patients treated in Botswana's National Antiretroviral treatment program. AIDS 2008;22:2303-11.

8. Theuring S, Mugeny K, Rubaihayo J, et al. Antiretroviral therapy programme retention and outcomes after 12 months in a retrospective patient cohort in Fort Portal, Uganda: the ongoing challenge of male ART performance. AIDS Clin Res 2015;6:423.

9. WHO. Antiretroviral therapy for HIV infection in adults and adolescents: recommendations for a public health approach 2010 revision. Geneva: WHO; 2010.

10. WHO/UNAIDS. Consolidated guidelines on the use of antiretroviral drugs for treating and preventing HIV infection: recommendations for a public health approach. Geneva: WHO; 2013.

11. Simmons RD, Ciancio BC, Kall MM, et al. Ten-year mortality trends among persons diagnosed with HIV infection in England and Wales in the era of antiretroviral therapy: AIDS remains a silent killer. HIV Med 2013;14:596-604.

12. Lewden C, Leport C, Cuzin L, et al. Prognostic factors of mortality in the APROCO-ANRS EP11 cohort of HIV-1 infected adults started on a protease inhibitor-containing therapy. 40th Interscience Conference on Antimicrobial Agents and Chemotherapy; Toronto, Ontario, Canada: Abstract 1909; 2000. p. Abstract 1909.

13. Corey DM, Kim HW, Salazar R, et al. Brief report: effectiveness of combination antiretroviral therapy on survival and opportunistic infections in a developing world setting: an observational cohort study. J Acquir Immune Defic Syndr 2007;44:451-5.

14. UNAIDS. HIV and AIDS Uganda Country Progress Report 2013. Geneva: UNAIDS; 2014. Contract No.: 10-07-2014.
15. WHO. Antiretroviral therapy for HIV infection in adults and adolescents; recommendations for a public health approach. Geneva: WHO; 2006.

16. Uganda Ministry of Health. Antiretroviral treatment policy. Kampala: Uganda Ministry of Health; 2009.

17. TASO. TASO Services and programmes Kampala: TASO; 2011. Available from: http://www.tasouganda.org/.

18. Egger M, Spycher BD, Sidle J, et al. Correcting mortality for loss to follow-up: a nomogram applied to antiretroviral treatment programmes in sub-Saharan Africa. PloS Med. 2011;8:e1000390.

19. Zachariah R, Fitzgerald M, Massaquoi M, et al. Risk factors for high early mortality in patients on antiretroviral treatment in a rural district of Malawi. AIDS 2006;20:2355-60.

20. Sieleunou I, Souleymanou M, Schonenberger A, et al. Determinants of survival in AIDS patients on antiretroviral therapy in a rural centre in the Far-North Province, Cameroon. Trop Med Int Health 2009;14:36-43.

21. Microsoft A, Ledergerber B, Katlama C, et al. Decline in the AIDS and death rates in the EuroSIDA study: an observational study. Lancet 2003;362:22-9.

22. Mermin J, Were W, Ekwaru J, et al. Mortality in HIV-infected Ugandan adults receiving antiretroviral treatment and survival of their HIV-uninfected children: a prospective cohort study. Lancet 2008;371:752-9.

23. Mermin J, Lule J, Ekwaru JP, et al. Effect of cotrimoxazole prophylaxis on morbidity, mortality, CD4 cell count, and viral load in HIV infection in rural Uganda. Lancet 2004;364:1428-34.

24. Mermin J, Lule J, Ekwaru J, et al. Cotrimoxazole prophylaxis by HIV-infected persons in Uganda reduces morbidity and mortality among HIV-uninfected family members. AIDS 2005;19:1035-42.

25. Suthar BA, Granich R, Mermin J, et al. Effect of cotrimoxazole on mortality in HIV-infected adults on antiretroviral therapy: a systematic review and meta-analysis. Bull World Health Organ 2012;90:128-38.

26. Walker AS, Ford D, Gilks CF, et al. Daily Cotrimoxazole prophylaxis in severely immune-suppressed HIV-infected adults in Africa started on combination antiretroviral therapy: an observational analysis of the DART cohort. Lancet 2010;375:127886.

27. Munro CA, Hube B. Anti fungal therapy at the HAART of viral therapy. Trends Microbiol 2002;10:173-7.

28. Chang LW, Phipps WT, Kennedy GE, et al. Antifungal interventions for the primary prevention of cryptococcal disease in adults with HIV. Hoboken: John Wiley \& Sons Ltd; 2005.

29. Weidle P, Wamai N, Solberg P, et al. Adherence to antiretroviral therapy in a home-based AIDS care programme in rural Uganda. Lancet 2006;368:1587-94.

30. Palella FJ, Delaney KM, Moorman AC, et al. Declining morbidity and mortality among patients with advanced human immunodeficiency virus infection. HIV outpatient study investigators. N Engl J Med 1998; 338:853-60.

31. Grimsrud A, Balkan S, Casas C, et al. Outcomes of antiretroviral therapy over a 10-year period of expansion: a multicohort analysis of african and asian HIV programs. J Acquir Immune Defic Syndr 2014;67:e55-66.

32. Kumarasamy N, Venkatesh KK, Devaleenal B, et al. Factors associated with mortality among HIV-infected patients in the era of highly active antiretroviral therapy in southern India. Int J Infect Dis 2010;14: e127-31.

33. Moh R, Daniel C, Messou E, et al. Incidents and determinants of mortality and morbidity following early antiretroviral initiation in HIV infected adults in West Africa. AIDS 2007;21:2483-91.

34. Mills EJ, Bakanda C, Birungi J, et al. Mortality by baseline CD4 cell count among HIV patients initiating antiretroviral therapy: evidence from a large cohort in Uganda. AIDS 2011;25:851-5.

35. Johannessen A, Naman E, Ngowi B, et al. Predictors of mortality in HIV-infected patients starting antiretroviral therapy in a rural hospital in Tanzania. BMC Infect Dis 2008;8:52.

36. Moore DM, Yiannoutsos CT, Musick SB, et al. Determinants of early and late mortality among HIV-infected individuals receiving home-based antiretroviral therapy in rural Uganda. J Acquir Immune Defic Syndr 2011;58:289-96.

37. Uganda Bureau of Statistics. Uganda Demographic and Health Survey. Calverton: UBOS and Macro International Inc.; 2006.

38. Kigozi IM, Dobkin LM, Martin JN, et al. Late-disease stage at presentation to an HIV clinic in the era of free antiretroviral therapy in Sub-Saharan Africa. J Acquir Immune Defic Syndr 2009;52:280-9.

39. Bakanda C, Birungi J, Mwesigwa J, et al. Survival of HIV-infected adolescents on antiretroviral therapy in Uganda: findings from a nationally representative cohort in Uganda. PLoS One 2011;6:e19261.

40. Moore A, Sabin C, Johnson M, et al. Gender and clinical outcomes after starting highly active antiretroviral treatment:a cohort study. J Acquir Immun Defic Syndr 2002;29:197-202. 
41. Kremer H, Sonnenberg-Schwan U. Women living with HIV. Does Sex and gender matter? A current literature review. Eur J Med Res 2003;8:8-16.

42. Zachariah R, Fitzgerald M, Massaquoi M, et al. Risk factors for high early mortality in patients on antiretroviral treatment in a rural district of Malawi. AIDS 2006;20:2355-60.

43. Iroezindu $\mathrm{M}$, Ofondu $\mathrm{E}$, Hausler $\mathrm{H}$, et al. Factors for opportunistic infections in HIV patients receiving antiretroviral therapy in a resource-limited setting in Nigeria. $\mathrm{J}$ AIDS Clinic Res 2013;S3:002.

44. Kikafunda K, Lukwago F. Nutritional status and functional ability of the elderly aged 60 to 90 years in the Mpigi district of central Uganda. Nutrition 2005;21:59-66.

45. Sobrino-Vegas P, Rodríguez-Urrego J, Berenguer J, et al. Educational gradient in HIV diagnosis delay, mortality, antiretroviral treatment initiation and response in a country with universal health care. Antivir Ther 2012;17:1-8.

46. Laidman J. Racial disparity in HIV mortality hits less educated hardest. Medscape Medical News, 2012.

47. García de Olalla P, Knobel H, Carmona A, et al. Impact of adherence and highly active antiretroviral therapy on survival in HIV- infected patients. J Acquir Immune Defic Syndr 2002;30:105-10.

48. Wood E, Hogg R, Yip B, et al. Effect of medication adherence on survival of HIVinfected adults who start highly active antiretroviral therapy when the CD4+ cell count is 0.200 to $0.350 \times 10(9)$ cells/L. Ann Intern Med 2003;139:810-16.

49. Abaasa A, Todd J, Ekoru K, et al. Good adherence to HAART and improved survival in a community HIV/AIDS treatment and care programme: the experience of The AIDS Support Organization (TASO), Kampala, Uganda. BMC Health Serv Res 2008;8:241. 